\title{
The Ninth Parliamentary Election of Sri Lanka in 2020: An Analysis of the Outcomes
}

\author{
Krishnamohan Thanabalasingam \\ Professor in Political Science \\ Eastern University, Sri Lanka, \\ Sri Lanka \\ krishnamohant@esn.ac.1k
}

\author{
Sathiyasegar Kandasamy \\ Senior Lecturer in Sociology and Anthropology \\ Eastern University, Sri Lanka, \\ Sri Lanka \\ sathiyasegarlgmail.com
}

DOI: 10.29322/IJSRP.10.10.2020.p10659

http://dx.doi.org/10.29322/IJSRP.10.10.2020.p10659

\begin{abstract}
The Sinhala Buddhists, who are the majority in Sri Lanka, helped the Sri Lanka Podujana Peramuna (SLPP) win an absolute majority in the ninth general election of Sri Lanka. The SLPP always wishes to exceed expectations and the president, who also belongs to the SLPP, claimed that the party's performance in the general election was better than what they had anticipated. The United National Party (UNP), led by the former Prime Minister Ranil Wickremesinghe, suffered the worst electoral defeat in their history as they managed to win only one seat, that too through the national list. Ranil Wickremesinghe also recorded his first defeat in an electoral battlefield. The Samagi Jana Balawegaya (SJB), led by Sajith Premadasa, that broke away from the UNP, managed to gain 54 seats and emerged as the secondlargest alliance in the island. The Tamil National Alliance (TNA), which used to enjoy the support of the majority in the North and East of Sri Lanka, suffered a huge setback as they ended up with only 10 seats, 6 less than what they had won in the previous general election. The SLPP managed to win approximately $59 \%$ of the popular vote while the SJB won almost $24 \%$ of the votes, becoming the second most popular party in the island ahead of the veteran parties like the UNP and TNA.
\end{abstract}

Key Words- Constitution, Election, Parliament, Women, Minorities

\section{INTRODUCTION}

Even though 16 million Sri Lankans were registered to vote to elect the members of Sri Lanka's ninth parliament, the election campaign was mostly affected by the COVID-19 pandemic. According to the voters' list of 2018, nearly $84 \%$ of the registered voters polled their votes in the last November 2019 Presidential election. Considering the voters' list of 2019 , total registered voters' numbers were $16,263,885$. But the polled votes fell to $12,343,308(75.89 \%)$ due to the public health issue. The Sri Lanka Podujana Peramuna (SLPP) contested against a weakened opposition party in the parliament election. Even though the parliamentary election was delayed twice due to the COVID-19, SLPP got 2/3 majority in the parliament with the help of other supporting parties. The SLPP was expecting to get the two-thirds majority (150 seats) in the parliament without other parties' support. But they were able to gain only 145 seats in the parliament. The parliamentary elections results may be seen as an indicator of its future political direction and help to increase the potential executive president's power. With obstacles from the COVID-19 pandemic, during which the election commission tried to make sure that polling was free, fair, and safe for all. Due to the inability of foreign election monitors to travel to the country due to the COVID-19 related restrictions in place, the election was monitored by local personnel. Therefore, this research article is focused on examining the following crucial problems:

1. Did the SLPP record a historic victory by gaining a total of 6.8 million Sinhalese cast votes $(59 \%$ of the valid votes) in the ninth parliamentary election?

2. Why did UNP-led United National Front for Good Governance secured 5.0 million votes in the 2015 General election but in the last parliament election, just secured only 249,435 votes?

3. How to evaluate the political status of minority parties in the ninth parliamentary election?

4. What, in the future, necessary strategies should be developed to ensure maximum security to the women's political participation?

This research paper consists of two parts. The first part of the research paper analyzes the parliament election results and SLPP's decisive victory. The second part of the research paper analyzes the minority political parties' status and women's political participation. This research was done qualitatively and involved analysis of the content of the events. The content analysis generally involved closely examining the text of documents and the words of politicians and political analysts. The data collected regarding the criticisms of the political 
ISSN 2250-3153

parties' manifesto of Sri Lanka on online literature, political leaders' speech, past election statistics, and research books have been used to write this research article.

\section{THEORY}

The primary norm of proportional representation (PR) is, every group of the society would secure their representation in the parliament, in proportion to their population. Different communities, who otherwise will go without representation, will get representation according to their strength in numbers. The main purpose of the PR system is to safeguard a representative assembly reflecting the statistical exactness of the various divisions in the constituency. Eminent political thinker J.S Mill supported the PR system (Agarwal, R.C, 1976). He says that a parliament must represent, all the divisions of the constituency and no minority should go without any representation in the parliament. The parliament is compared to maps. One cannot draw a map of a country ignoring any part of the area of the country. All the areas of the country should be represented in the map. Similarly, all the areas of the constituency should be represented in the parliament. The PR system has two methods. One is the Hare system and the other one is the List system. Hare systems is also known by other names such as preferential system or the single transferable vote system. The voters exercise many votes as there are several candidates and indicates their preferences of the candidates for whom they vote. In the list system candidates are grouped into lists, with each party representing a separate list. A voter casts vote for a list. Every party offers a list of its candidates up to the number of seats to be filled from each constituency. A voter cast vote for the list she/he likes. She/he may cast vote either for one candidate on the list or may distribute all his votes to the different candidates on the same list. But she/he cannot cast more than one vote to any candidates. This system gives the opportunity of representation to all parties, big or small, and confirms that the parliament mirrors the view of all the people (Agarwal, R.C, 1976). Under this system, even a minor or numerically small group of people may send a representative if they can organize themselves to cast the votes in favour of a candidate. In the same way, even a small party can get the number of its members elected with the help of constituencies of a district in which it is popular. PR satisfies its aim by giving equal chances to the minority.

The aim of the PR system allocates seats in the legislature according to the casted number of votes to the political parties or independent groups. Let's consider this scenario as an example. Based on the constituency, five seats are allowed from a certain district or area. A party polling three fifth of the total casting votes by the voters in that constituency will return three out of five seats. Another party polling two fifth of the total cast votes will return two seats. The party composition of the legislature reflects the party preference of the electorate with a considerable degree of accuracy in the electorate. For example, hypothetical table 1 shows a legislature with five seats with 200,000 voters in an electorate.

TABLE I

HYPOTHETICAL TABLE

\begin{tabular}{|l|cc|c|c|c|}
\hline \multirow{2}{*}{ Party } & \multicolumn{2}{|c|}{ Votes } & \multicolumn{2}{c|}{ Seats in the Body } \\
\cline { 2 - 6 } & \multicolumn{2}{|c|}{$\begin{array}{c}\text { Casted } \\
\text { Votes }\end{array}$} & Percentage & $\begin{array}{c}\text { Number } \\
\text { of Returned }\end{array}$ & Percentage \\
\hline A & 0 & 120,00 & $60 \%$ & 3 & $60 \%$ \\
\hline B & 80,000 & $40 \%$ & 2 & $40 \%$ \\
\hline Total & 200,00 & $100 \%$ & 5 & $100 \%$ \\
\hline
\end{tabular}

\section{DISSOLVING the PARLIAMENT and COVID -19}

The President can dissolve the parliament four and a half (4-1 / 2) years after the commencement of the term of office of a parliament of Sri Lanka. The power to dissolve parliament is vested in the President by Article 70 (10) and section (2) (e) of the constitution. Therefore, following these provisions, and per the provisions of section 10 of the parliamentary elections Act No. 1 of 1981, the President of the Democratic Socialist Republic of Sri Lanka, Gotabhaya Rajapaksa, dissolved the parliament at midnight on March 2, 2020, and announced the election for a new parliament will be held on April 25. He also called on the new parliament to begin its session on May 14, 2020 (The Gazette of The Democratic Socialist Republic of Sri Lanka, Extraordinary, No. 2165/8 - Monday, March 02, 2020).

During this period, the COVID-19 pandemic began to spread in Sri Lanka. On March 19, Election Commission announced that the parliamentary elections would be postponed indefinitely, referring to instructions from the Government Medical Officers' Association (GMOA) that the country's health and medical conditions were in jeopardy. Despite the COVID-19 pandemic in Sri Lanka, the government was stubborn that elections should be held on April 25 as planned. Against the government move, the Election Commission banned political parties from holding election rallies, mass meetings, and campaigns. However, during a video conference with SAARC heads of state, Sri Lankan president Gotabhaya Rajapakse reaffirmed that the parliamentary elections would go ahead as planned.

Ignoring the president's urgency and focus on holding the parliamentary elections as planned, the Election Commission of Sri Lanka postponed the parliamentary elections until June 20, using its powers. The Election Commission also wrote a letter to the president on April 3, asking the president to seek the advice from the Supreme Court on announcing a new date 
ISSN 2250-3153

considering the constitution, and the health and medical conditions of the country.

The President's office had no intention of seeking advice from the Supreme Court on holding parliamentary elections. On April 9, the secretary to the president responded in writing that it was the duty of the Election Commission to abandon its warning of a constitutional crisis and hold parliamentary elections. Finally, the parliamentary elections were not held on April 25 amid the spreading COVID -19 pandemic. And the Election Commission decided to postpone the general election until June 20. On May 28, one of the members of the Election Commission expressed his view opposing the holding of the election under the influence of the government. This was again seen as a matter of crisis between the president and the constitution and was considered a fundamental rights issue and turned into a matter for the Supreme Court.

As a challenge to the Gazette notice, the newspaper editor Victor Ivan and seven others on $5^{\text {th }}$ May 2020, Samagi Jana Balawegaya and Champika Ranawaka of Jathika Hela Urumaya on $6^{\text {th }}$ May 2020, Kumara Welgama of New Sri Lanka Freedom Party on $9^{\text {th }}$ May, filed a fundamental rights in the Supreme court (Colombo Page News Desk, Jun 2, 2020).

The petition stated, holding parliamentary elections on June 20 is against the provisions of the constitution. The petitioners also contended that the president's gazette notification on dissolving the parliament was invalid as the new parliament could not be convened within three months of its dissolution. Moreover, the petitioners have observed that free and fair elections cannot be held in the context of the COVID -19 crisis as the pandemic has not yet been brought under control. The health-related risk will seriously hamper the campaign efforts and they needed free and fair elections. The petitioners, therefore, asked the Supreme Court to give a verdict that the fundamental rights of the people are being violated by holding elections before the conclusion of the COVID -19-virus pandemic.

A five-member panel of the Supreme Court judges began the hearings on May $18^{\text {th }}$ to determine whether all the seven petitions filed against the general election scheduled for June 20 should be taken up for the hearing or not. After a ten-days hearing, the five Supreme Court judges unanimously dismissed the case, saying the petitions would not be heard. Following this, the Election Commission announced August $5^{\text {th }}, 2020$, as the new date for holding parliamentary elections (Colombo Page News Desk, Jun 2, 2020).

\section{ELECTORAL SYSTEM of the PARLIAMENT ELECTION of SRI LANKA}

The electoral system operates at three levels such as national, provincial, and local in Sri Lanka. For administrative purposes, the country has been divided into 25 administrative districts. Article 96 (1) says that to hold elections, the country can be divided into not less than twenty and not more than twenty-five electoral districts. According to Article 96 (1) \& (2), the country has been divided into 22 electoral districts for electoral purposes, of these 20 electoral districts have coboundary with the 25 electoral districts. According to Article 96 (3), an electoral district namely Vanni has been formed by the Delimitation Commission who combined three administrative districts, namely, Mullaitivu, Mannar, and Vavuniya. The same way other an electoral district namely Jaffna has been formed by the Delimitation Commission who combined two administrative districts such as Jaffna and Kilinochchi. The above 22 electoral districts have been divided into 160 polling divisions. Article 94 (4) says that the electoral districts of each province shall be altogether entitled to elect four (4) members. Article 98 (1) says that the 22 electoral districts shall together be entitled to elect one hundred and ninety-six (196) members for the parliament. In this way, 160 parliament members shall be elected by 160 poling divisions from 22 electoral districts and besides based on Article 98 (2), each electoral district shall elect thirty-six (36) parliament members (The Constitution of the Democratic Socialist Republic of Sri Lanka,2015).

Thus, the country is divided into 22 electoral districts for parliamentary elections and each of these districts becomes a constituency. According to Article 98 (4), the total number of electors whose names appear in the registers of electors of all the electoral districts shall be divided into one hundred and sixty. The whole number, resulting from dividing numbers (any fraction numbers not being considered) is hereinafter referred to as the "qualifying number".

According to the constitution, any person qualified to be a voter is qualified to be elected as a member of parliament. The parliamentary elections in Sri Lanka are held on the PR system. The number of members of parliament to be elected from each constituency is determined on a formula based on the total number of voters in the country. A political party or an independent group expecting to contest a constituency should submit a list of names of candidates. Such a list should contain three names more than the number of members to be elected. A voter is entitled to one vote which must be cast for the political party or the independent group of her/his choice. She/he is also entitled to mark up to three preferences against the names of three candidates of the political party or the independent group he votes for. The number of members elected from a political party or an independent group at an election is determined based on the votes received by the political party or group in the entire electorate.

196 candidates were elected from twenty-two electoral district in the nine electoral provinces. Each electoral district consists of different numbers of members based on the population of voters like it show below (Daily FT, Wednesday, 5 August 2020 03:43). 
TABLE II

COMPOSITION of MEMBERS in the $9^{\mathrm{TH}}$ PARLIAMENT-2020

\begin{tabular}{|c|c|c|c|c|c|}
\hline No & $\begin{array}{l}\text { Electoral } \\
\text { Provinces }\end{array}$ & Electoral District & $\begin{array}{l}\text { Elected } \\
\text { Candidates in } \\
\text { the District } \\
\text { Level }\end{array}$ & \begin{tabular}{l}
\multicolumn{1}{c}{ Elected } \\
Members in the \\
Provincial Level
\end{tabular} & $\begin{array}{l}\text { Contested } \\
\text { Candidates }\end{array}$ \\
\hline \multirow[t]{3}{*}{1} & \multirow[t]{3}{*}{ Western } & Colombo & 19 & \multirow{3}{*}{47} & 924 \\
\hline & & Gampaha & 18 & & 693 \\
\hline & & Kalutara & 10 & & 312 \\
\hline \multirow[t]{3}{*}{2} & \multirow[t]{3}{*}{ Central } & Kandy & 12 & \multirow{3}{*}{25} & 435 \\
\hline & & Nuwara Eliya & 08 & & 275 \\
\hline & & Matale & 05 & & 184 \\
\hline \multirow[t]{3}{*}{3} & \multirow[t]{3}{*}{ Southern } & Galle & 09 & \multirow{3}{*}{23} & 312 \\
\hline & & Matara & 07 & & 200 \\
\hline & & Hambantota & 07 & & 190 \\
\hline \multirow[t]{2}{*}{$\overline{4}$} & \multirow[t]{2}{*}{ North-West } & Kurunegala & 15 & \multirow{2}{*}{23} & 396 \\
\hline & & Puttalam & 08 & & 352 \\
\hline \multirow[t]{2}{*}{5} & \multirow[t]{2}{*}{ Sabaragamuwa } & Ratnapura & 11 & \multirow{2}{*}{20} & 308 \\
\hline & & Kegalle & 09 & & 228 \\
\hline \multirow[t]{3}{*}{6} & \multirow[t]{3}{*}{ Eastern } & Digamadulla & 07 & \multirow{3}{*}{16} & 540 \\
\hline & & Batticaloa & 05 & & 304 \\
\hline & & Trincomalee & 04 & & 189 \\
\hline \multirow[t]{2}{*}{7} & \multirow[t]{2}{*}{ North -Central } & Anuradhapura & 09 & \multirow{2}{*}{14} & 264 \\
\hline & & Polonnaruwa & 05 & & 152 \\
\hline \multirow[t]{2}{*}{8} & \multirow[t]{2}{*}{ Uva } & Badulla & 09 & \multirow{2}{*}{15} & 288 \\
\hline & & Monaragala & 06 & & 171 \\
\hline \multirow[t]{2}{*}{9} & \multirow[t]{2}{*}{ Northern } & Jaffna & 07 & \multirow{2}{*}{13} & 330 \\
\hline & & Vanni & 06 & & 405 \\
\hline \multicolumn{2}{|c|}{ Total } & & 196 & 196 & 7452 \\
\hline
\end{tabular}

Source: $5^{\text {th }}$ August 2020 Sri Lankan Parliamentary Elections, Election Commission

\section{NINTH PARLIAMENT of SRI LANKA}

The Election Commission announced on August $5^{\text {th }}, 2020$, as the new date for holding parliamentary elections. In the 2020 parliamentary election, almost 16 million voters casted their votes in 22 electoral districts, 7452 candidates contested from recognized political parties, and independent groups. Amongst, those 3652 candidates were from recognized political parties and 3800 candidates were from independent groups. A total of 313 independent groups contested in the 2020 parliamentary election. Among the 7452 candidates, 196 candidates were elected as parliamentarians out of 225 at the district level under the PR system. And the rest of the 29 members were nominated through the national list under the 1978 constitution (Daily FT, Wednesday, 5 August 2020 03:43). It shows in the table:3 below.
TABLE III

$9^{\mathrm{TH}}$ PARLIAMENT ELECTION ACTIVITIES- AUGUST 5, 2020

\begin{tabular}{|l|l|}
\hline Description & Amount \\
\hline Total Parliament MPs & 225 \\
\hline Elected Members & 196 \\
\hline National List Members & 29 \\
\hline No. of Candidates & 7,452 \\
\hline No of Eligible Voters & $16,263,885$ \\
\hline Electoral District & 22 \\
\hline Polling Stations & 12,985 \\
\hline Policemen on Election Duty & 82,000 \\
\hline Health Service on Election Duty & 8,000 \\
\hline
\end{tabular}

Source: Daily FT, Wednesday, 5 August 2020

Even though in the 2015 parliamentary election more political parties and independent groups contested, only six 
ISSN 2250-3153

political parties were able to represent their members in the parliament (General Election, 2015). They are the United National Party (UNP), the United People's Freedom Alliance (UPFA), the Ilankai Tamil Arasu Kachchi (ITAK), the People's Liberation Front (JVP), the Sri Lanka Muslim Congress (SLMC) and the Eelam People's Democratic Party (EPDP)

But in the parliamentary elections held on August 5, 2020, fifteen political parties fielded their members in the parliament (General Election, 2015). The SLPP gained most of the seats at the parliamentary general election in 2020. Other political parties to obtain seats in parliament general election were the
Samagi Jana Balawegaya (SJB), Illankai Tamil Arasu Kadchi (ITAK), Jathika Jana Balawegaya (JJB), Eelam People's Democratic Party (EPDP), Ahila Ilankai Thamil Congress (AITC), Thamil Makkal Viduthalai Pulikal (TMVP), Sri Lanka Freedom Party (SLFP), Muslim National Alliance (MNA), Thamil Makkal Thesiya Kuttani (TMTK), All Ceylon Makkal Congress (ACMC), National Congress (NC), Sri Lanka Muslim Congress (SLMC), United National Party (UNP) and the Our Power of People Party (OPPP). Given below is a table showing the distribution of seats for each political party (Parliament of Sri Lanka, Monday, August 10, 2020)

TABLE IV

VOTES, SEATS \& NATIONAL LIST BY PARTY - ALL ISLAND 2020

\begin{tabular}{|c|c|c|c|c|c|c|}
\hline S.No & Party & Votes & $\%$ & Elected Seats & $\begin{array}{l}\text { National } \\
\text { List }\end{array}$ & Total Seats \\
\hline 1 & SLPP & $6,853,690$ & 59.09 & 128 & 17 & 145 \\
\hline 2 & SJB & $2,771,980$ & 23.90 & 47 & 7 & 54 \\
\hline 3 & ITAK & 327,168 & 2.82 & 9 & 1 & 10 \\
\hline 4 & JJB & 445,958 & 3.84 & 2 & 1 & 3 \\
\hline 5 & AITC & 67,766 & 0.58 & 1 & 1 & 2 \\
\hline 6 & EPDP & 61,464 & 0.53 & 2 & 0 & 2 \\
\hline 7 & UNP & 249,435 & 2.15 & 0 & 1 & 1 \\
\hline 8 & OPPP & 67,758 & 0.58 & 0 & 1 & 1 \\
\hline 9 & $\begin{array}{ll} & \text { TMV } \\
\mathrm{P} & \\
\end{array}$ & 67,692 & 0.58 & 1 & 0 & 1 \\
\hline 10 & SLFP & 66,579 & 0.57 & 1 & 0 & 1 \\
\hline 11 & MNA & 55,981 & 0.48 & 1 & 0 & 1 \\
\hline 12 & $\begin{array}{ll} & \text { TMT } \\
\mathrm{K} & \\
\end{array}$ & 51,301 & 0.44 & 1 & 0 & 1 \\
\hline 13 & $\mathrm{C}{ }^{\mathrm{ACM}}$ & 43,310 & 0.37 & 1 & 0 & 1 \\
\hline 14 & $\mathrm{NC}$ & 39,272 & 0.34 & 1 & 0 & 1 \\
\hline 15 & $\begin{array}{ll} & \text { SLM } \\
\mathrm{C} & \\
\end{array}$ & 34,428 & 0.39 & 1 & 0 & 1 \\
\hline & Total & & & 196 & 29 & 225 \\
\hline
\end{tabular}

Source: Parliament of Sri Lanka, Monday, August 10, 2020

The SLPP recorded a historic victory with 145 seats through gaining a total of 6.8 million cast votes with $59 \%$ of the valid votes in the ninth parliamentary election. The SLPP secured 6.9 million votes in the November 2019 presidential election but in the last parliament election, just about one hundred thousand votes were lost due to various political scenarios. Like the parliamentary election victory back in 2010, after ending the civil war with LTTE, the SLPP's performance in the 2020 parliament election was very impressive in many ways.
The election results show that the SLPP's landslide victory was recorded mostly with Sinhalese votes. Except for Sathasivam Viyalendiran in the Batticaloa district, Jeevan Thondaman, and M. Rameshwaran in the Nuwara Eliya district and Kader Mastan in the Vanni district, all the other SLPP candidates were elected by the Sinhalese votes in Sri Lanka. Therefore, it can be argued that out of the 145 seats won by SLPP, 141 seats were won with Sinhala voters. SLPP has created a government of the Sinhalese without the support of the minority people, who were considered as kingmakers of the previous government. As diplomatically, SLPP succeeded in carrying out anti-minority propaganda among the majority 
Sinhalese population. The SLPP then appointed three Muslim MPs and one Tamil MP as members of parliament while appointing the members of the national list. It is an attempt to provide a small relief to the mental anguish caused to the minority people during the campaign and to spread the message that a government has been established that will incorporate and rule all the people of the country.

The ninth parliament election result in Sri Lanka has once more confirmed that Mahinda Rajapaksa is the preferred Sinhala Buddhist leader by the majority of people. And 2019 Presidential election results have made Gotabaya Rajapaksa, who is the younger brother of Mahinda Rajapaksha, as the most powerful president of the country. Kusal Perera, a veteran political analyst, writer, and a strong critic of governments, said: "Yes, Sri Lanka has been gradually turning into a majoritarian country... That is what is guaranteed in these two elections - November's Presidential victory and this Parliamentary result" (Indian Express, August 9, 2020, 10:33:48 am). The poll results indicated nothing but the fact that Sri Lankan people wanted a strongly Sinhala Buddhist leader. Mahinda Rajapaksa is the most popular leader; Gotabaya Rajapaksa is the most powerful leader. They have big challenges in front of them without provoking racism, should plan and go forward with suitable developmentoriented policies, without discriminating the Sri Lankans. Gotabaya Rajapaksa has foreign exposure and knowledge, he knows that development-oriented policies alone will save the country and he is working towards that, to improve the economy.

An equally important scenario of the 2020 general election has been the downfall of the UNP. The UNP is the largest and liberal party in the history of Sri Lanka. Since the party was founded by the first prime minister of Sri Lanka's D.S. Senanayake on 6 September 1946. It has come to power for 36 times in the 72 years of the post-independence of Sri Lanka. The UNP has a noble history as it has made six heads of government. They are, namely, D.S. Senanayake, Dudley Senanayake, Sir John Kotelawala, J.R. Jayewardene, Ranasinghe Premadasa, and D.B. Wijetunga. (Presidential Secretariat,2020). However, Ranasinghe Premadasa was the last elected head of government from the UNP, he was assassinated by the LTTE in May 1993. In the last parliament election, there was a split between the two leaders and contesting separately, with former Prime Minister Ranil Wickremasinghe led the UNP, and Sajith Premadasa led the breakaway faction, the Samagi Jana Balawegaya (SJB). UNP leader Ranil Wickremasinghe met the first historical letdown in his political career in last parliament election. UNP secured only 249,435 votes or $2.15 \%$ of the total valid votes. They could not gain one seat in the parliament too. They gained only one national list seat in the parliament. While UNP lost all its seats, its substitute party Samagi Jana Balawegaya (SJB) alliance gained reasonable seats in the parliament. It was led by Sajith Premadasa, who is the son of the former president Premadasa who was the leader of the UNP. The SJB came in a second winner and Sajith Premadasa secured the status of the opposition party leader in the ninth parliament. The SJB secured $24 \%$ of the popular vote and 54 parliamentary seats including seven national list seats. It is noted that in the 2010 parliamentary election, UNP's got $29 \%$ of the popular vote and 60 parliament seats. Two SJB partner parties, the SLMC, and the ACMC secured a seat each under their flag, which made an effective opposition with 56 members of parliament.

\section{WOMEN REPRESENTATION}

Women comprise over $50 \%$ of the total population in Sri Lanka. Although, when it comes to political participation at the local and national levels, the number of women politicians is at a very minimal level in the country. Sri Lanka enjoyed electing the world's first woman prime minister who served three terms in that capacity and her daughter Chandrika Bandaranaike Kumaratunga served as a president for two consecutive terms. After that Sri Lanka has not witnessed any notable progress in women's participation in politics.

When taking into consideration women's representation in the 2020 parliament election, there were nearly 59 women representatives who received nominations from various political parties to contest in the parliamentary election 2020, but only eight (8) candidates won the election. Also, four (4) women selected to the parliament, as national lists members, where two representatives from SLPP, one from SJB, and one from Jathika Jana Balawegaya (JJB). Altogether, twelve (12) women were selected as a member of parliament out of 225 in the 9th parliament (News wire,14.08.2020). It shows the table:5 below.

TABLE V

WOMEN IN THE $9^{\text {TH }}$ PARLIAMENT

\begin{tabular}{|l|l|l|}
\hline \multicolumn{1}{|c|}{ Party } & \multicolumn{1}{|c|}{ District } & Name \\
\hline \multirow{3}{*}{ SLPP } & \multirow{2}{*}{ Ratnapura } & Pavithra Wanniarachchi \\
\cline { 3 - 3 } & & Muditha Soyza \\
\cline { 3 - 3 } SJB & & Thalatha Athukorale \\
\hline SLPP & Kegalle & Rajika Wickremesinghe \\
\hline SLPP & Gampaha & Sudharshani Fernandopille \\
\cline { 3 - 3 } & & Kokila Gunawardene \\
\cline { 3 - 3 } & Galle & Geetha Kumarasinghe \\
\hline SJB & Matale & Rohini Kaviratne \\
\hline \multirow{3}{*}{ SLPP } & National List & Seetha Arambepola \\
\hline SJB & & Manjula Dissanayake \\
\hline JJB & & Diana Gamage \\
\cline { 3 - 3 } & & Harini Amarasuriya \\
\cline { 3 - 3 } & & \\
\hline
\end{tabular}

Source: The Gazette of the Democratic Socialist Republic of Sri Lanka, Extraordinary, No. 2187/26

According to the web site of the women's national parliament archive, in 2018, Pakistan secured 20.2\% women representation in the lower house and $19.2 \%$ in the upper house. In 2018, Bangladesh secured 20.7\% of women's representation in parliament. In $2017 \mathrm{Nepal}$ secured 32.7\% of women representation in the lower house and $37.3 \%$ in the upper house. In 2014, India secured $12.6 \%$ women 
representation in the lower house and $11.5 \%$ in the upper house (Women in national parliaments,2019).

While compared South Asia with Sri Lanka's experience, from 1994 to 2020, it indicated that women's participation in Sri Lanka is at a very minimal level. The below chart indicates that the reality of Sri Lanka's women's political participation in the last thirty years. The women activists' concern is that women's representation in the parliament increased only so far $5.3 \%$ in the history of Sri Lanka (Parliament of Sri Lanka, Lady Members). It is shown in the figure I below.

FIGURE I

WOMEN REPRESENTATION IN THE PARLIAMENT FROM1994

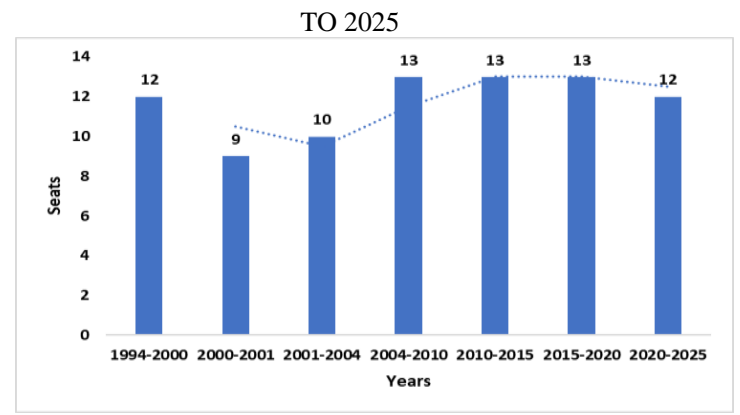

Source: Parliament of Sri Lanka, Lady Members

Forty-eight (48) members have been elected to the parliament on behalf of the minority people in the recent parliamentary elections in 2020. Twenty-eight of them (28) represent the Tamil people from different parts of the country on behalf of different political parties and of the twenty-eight members, twenty-five members have been elected from deferent districts. The other three members were selected through the respective political party's national list (The Gazette of the Democratic Socialist Republic of Sri Lanka, Extraordinary, No. 2187/26). It is shown in the table VI below.

TABLE VI

TAMIL MEMBERS in the $9^{\text {TH }}$ PARLIAMENT ELECTION 2020

\begin{tabular}{|l|l|l|l|l|l|l|l|l|l|}
\hline Methods & ITAK & SJB & SLFP & EPDP & AITC & TMVP & TMTK & SLPP & Total \\
\hline Elected & 9 & 7 & 1 & 2 & 1 & 1 & 1 & 3 & 25 \\
\hline National List & 1 & & & & 1 & & & 03 \\
\hline Total & & & & & \\
\hline
\end{tabular}

Source: The Gazette of the Democratic Socialist Republic of Sri Lanka, Extraordinary, No. 2187/26

\section{TAMIL and MUSLIMS MEMBERS in the $9^{\mathrm{TH}}$ PARLIAMENT}

In the year 2001, the Tamil United Liberation Front (TULF) prominent leaders formed a new political wing, which is named as the Tamil National Alliance (TNA), with uniting all other moderate Tamil political parties and some ex-militant groups. It contested in the parliamentary election held on $5^{\text {th }}$ December 2001 under the TULF symbol and secured $3.89 \%$ $(348,164)$ votes won 15 seats in the North and Eastern Province.

At present, three political parties like ITAK, PLOTE, and TELO came under one umbrella in the name of TNA. In the last general election for the $9^{\text {th }}$ parliament, TNA suffered a setback in the north and east, they secured only 325,168 votes and gained nine seats. Out of nine seats, ITAK won five seats including two seats from Jaffna, one seat from Vanni, Batticaloa, and Trincomalee district. In the other four seats, the TELO won two seats from Vanni and one seat from Batticaloa, and the PLOTE won the one seat from Jaffna
District and but no candidate was nominated in the Batticaloa district representing PLOTE. But the ex-candidate of the PLOTE contested for SLPP and won the seat in the Batticaloa district. Now he is a State Minister of Postal Services and Professional Development of Journalists in the SLPP Government (The Gazette of the Democratic Socialist Republic of Sri Lanka, Extraordinary, No. 2187/26).

Comparing with the previous election, we can say, that the TNA's best election period was in 2004 of the parliamentary election, they secured $6.84 \%$ of the popular votes $(633,654)$ and secured 22 seats. Furthermore, following election periods, they secured $2.90 \%(233,190)$ votes and 14 seats in 2010 , $4.62 \%(515,963)$ votes and 16 seats in 2015 and $2.82 \%$ $(327,168)$ votes and 10 seats in 2020.

Twenty (20) represent the Muslim people from different parts of the country on behalf of different political parties and of the 20 members, sixteen members have been elected deferent district. The other four members were selected through the respective political party's national list (The Gazette 
TABLE VII

MUSLIMS MEMBERS in the $9^{\text {TH }}$ PARLIAMENT ELECTION 2020
\begin{tabular}{|l|l|l|l|l|l|l|r|}
\hline Methods & SJB & SLPP & NC & ACMC & SLMC & MNA & Total \\
\hline Elected & 11 & 1 & 1 & 1 & 1 & 1 & 16 \\
\hline $\begin{array}{l}\text { National } \\
\text { List }\end{array}$ & 1 & 3 & & & & & 04 \\
\hline Total & & & & & & 20 \\
\hline
\end{tabular}
Source: The Gazette of the Democratic Socialist Republic of Sri Lanka,
Extraordinary, No. 2187/26

\section{CONCLUSION}

The outcome of the election will make a significant impact on the constitutional amendment. Gotabaya Rajapaksa was elected as president in late 2019. Following the 2019 April 21 st Easter attack, he has led a national security and pronationalism campaign camp. Through this, he was beloved by Sinhalese ethnic majority though he could not gain the favoritism from Tamil ethnic and Muslim religious minorities. The SLPP now has sustained a strong position in the parliament. Its victory affirmed that the president's nationalist agenda and encouraged many of his policy positions. The objective of the party, to gain a two-thirds majority in the parliament. The two-third majority, which is the need for SLPP's governance to amend the country's political structure. specifically, by repealing the constitution's $19^{\text {th }}$ Amendment, to increase presidential powers relative to parliament and the judiciary. The SLPP is in a clear stand in their plans to amend the $19^{\text {th }}$ Amendment.

The people of Sri Lanka have strong political party affiliations. Based on that, people had voted their preferred political party in the last general election. But all of them, have a dual role in the general election, one is to give the party loyalty, and another one is to be an independent voter. But people failed to reject the candidates with the records of serious crime, financial fraud, inability, selfish and abused power while holding the public office in the last general election. In the year 2009, the 30-year armed struggle came to end. But yet, the issues that contributed to this civil war has been not resolved. For the resolving issues, the previous governments had appointed many commissions and expert committees. The previous governments supported arrangements for power-sharing and gave public assurances in this regard. On the perspective of Sri Lankan minorities, the people of Sri Lanka voted for the candidates who are yet to understand the need for diversity in the society and to the governance that promotes violence and discrimination against minority communities.

But all ethnic groups of Sri Lanka have indeed voted for a government that gives importance to the Economic Development. Even the Tamil ethnic minority have given their importance to Economy development along with their ethnic rights.

\section{REFERENCE}

I. Agarwal, R.C, 1976, Political Theory, Chand \& Company LTD, New Delhi

II. Colombo Page News Desk, Sri Lanka, Sri Lanka Supreme Court Allows Dissolution of parliament and June 20 election Tue, Jun 2, 2020, 08:58 pm SL Time, URL Available on

http://www.colombopage.com/archive_20A/Jun02_1 591111706CH.php

III. Dieter, Nohlen,1976, Election and Electoral System, Macmillan, New Delhi

IV. Explained: What the massive election victory for Rajapaksa means for Sri Lanka, Indian express, August 9, 2020, 10:33:48 am, URL Available on https://indianexpress.com/article/explained/sri-lankaparliamentary-election-results-mahinda-rajapaksa$\underline{6543889 /}$

V. General Election 2015, Parliament of Sri Lanka, URL Available on https://www.parliament.lk/election-2015

VI. General Election 2020, Parliament of Sri Lanka, URL Available on https://www.parliament.lk/election-2020

VII. News wire, 14.08.2020, Female representation in 9th Parliament of SL increases to 12, URL Available on http://www.newswire.lk/2020/08/14/18558-female/

VIII. Parliament of Sri Lanka, Monday, August 10, 2020, Results URL Available on, https://www.parliament.lk/election-2020/

IX. Parliament of Sri Lanka, Lady Members, URL Available on, https://www.parliament.lk/en/lady$\underline{\text { members }}$

X. People to polls for new P'ment today, Daily FT, Wednesday, 5 August 2020 03:43, URL Available on http://www.ft.lk/top-story/People-to-polls-for-new-Pment-today/26-704117

XI. Sri Lanka Consolidated Acts, Parliament Elections Act (No. 1 of 1981) - Sect 10, URL Available on http://www.commonlii.org/lk/legis/num_act/pea1o19 $\underline{81259 / \mathrm{s} 10 . \mathrm{html}}$ 
XII. The Constitution of the Democratic Socialist Republic of Sri Lanka (As Amended Up to $15^{\text {th }}$

XIII. parliament secretariat, URL Available on XVII. https://www.parliament.lk/files/pdf/constitution.pdf

XIV. The Gazette of The Democratic Socialist Republic of Sri Lanka, Extraordinary, No. 2165/8 - Monday, March 02, 2020, URL Available on http://www.documents.gov.lk/files/egz/2020/3/216508_E.pdf

XV. The Gazette of the Democratic Socialist Republic of Sri Lanka, Extraordinary, No. 2187/26 - Saturday, August 08, 2020, URL Available on https://www.parliament.lk/uploads/documents/gazett es/20200808-2187-26-en.pdf

XVI. The Gazette of the Democratic Socialist Republic of Sri Lanka, Extraordinary, Declaration under Article 99A of the Constitution, No. 2188/2 - Monday, August 10, 2020, URL Available on https://www.parliament.lk/uploads/documents/gazett es/20200810-2188-2-en.pdf
May 2015) Revised Edition - 2015, Published by the

XVII. The Gazette of the Democratic Socialist Republic of Sri Lanka, Extraordinary, Declaration under Article 99A of the Constitution, No. 2188/46 - Friday, August 14, 2020, URL Available on https://www.parliament.lk/uploads/documents/gazett es/20200814-2188-46-en.pdf

XVIII. The Scribd, 2020 General Election of Sri Lanka All-Island Final Result - Votes, Seats and National List, on Aug 06, 2020, URL Available on https://www.scribd.com/document/471648359/2020General-Election-of-Sri-Lanka-All-Island-FinalResult-Votes-Seats-and-National-List\#from_embed

XIX. Women in national parliaments, Situation as of $1^{\text {st }}$ February 2019, URL Available on http://archive.ipu.org/wmn-e/classif.htm

XX. $\quad 2020$ Sri Lankan parliamentary elections, Final Island wide Results, URL Available on https://results.elections.gov.lk/ 